\title{
Enforcement of Foreign Arbitration Agreements and Awards: Application of the New York Convention in the United States
}

Louis Del Duca

Nancy A. Welsh

Texas A\&M University School of Law, nwelsh@law.tamu.edu

Follow this and additional works at: https://scholarship.law.tamu.edu/facscholar

Part of the Civil Procedure Commons, Dispute Resolution and Arbitration Commons, and the International Law Commons

\section{Recommended Citation}

Louis Del Duca \& Nancy A. Welsh, Enforcement of Foreign Arbitration Agreements and Awards: Application of the New York Convention in the United States, 62 Am. J. Comp. L. Supp. 69 (2014). Available at: https://scholarship.law.tamu.edu/facscholar/943

This Article is brought to you for free and open access by Texas A\&M Law Scholarship. It has been accepted for inclusion in Faculty Scholarship by an authorized administrator of Texas A\&M Law Scholarship. For more information, please contact aretteen@law.tamu.edu. 


\section{LOUIS DEL DUCA AND NANCY A. WELSH*}

\section{Enforcement of Foreign Arbitration Agreements and Awards: Application of the New York Convention in the United States**†}

\section{Topic I. C}

International commercial arbitration provides customized and efficient resolution for disputes arising out of transnational commerce. When arbitration occurs in states that have ratified the New York Convention, the process also offers enforceable outcomes even in states other than the one where the arbitration occurred. The United States ratified the New York Convention in 1970, and its courts overwhelmingly enforce both arbitration agreements and arbitral awards. There are exceptions, however, and American courts require the use of certain procedures.

This Article provides a brief survey of American courts' recognition and enforcement of foreign arbitration agreements and arbitral awards. It begins by examining the extent of the reciprocity and commercial reservations made by the United States and the circumstances under which the Panama Convention preempts the New York Convention. Turning to the enforcement of arbitration agreements and clauses, the Article examines American courts' interpretations of the Convention's requirement of a signed agreement in writing and the circumstances that can make an arbitration agreement "null and void" or "incapable of being performed." The Article also summarizes courts' treatment of claims of waiver and lack of knowledge regarding the existence of arbitration clauses. Regarding American courts' enforcement of arbitral awards, the Article addresses the following

* Louis Del Duca is the Edward N. Polisher Distinguished Faculty Scholar Emeritus at Penn State University, Dickinson School of Law. Nancy A. Welsh is the William Trickett Faculty Scholar and Professor of Law at Penn State University, Dickinson School of Law. We are indebted to Dane Henry (J.D. 2014), Maren Miller (J.D. 2013), Katie Rimpfel (J.D. 2014), Kevin Schock (J.D. 2014), Anna Strawn (J.D. 2013), Brandon Toomey (J.D. 2014), Brian Brodeur (J.D. 2015), and Stephanie Sweeney (J.D. Candidate 2015) of Penn State University, Dickinson School of Law, for their assistance with the research and development of this article.

**: Due to space limitations, this is a condensed version of the full report of the United States Reporters to the General Reporter, George Bermann. The full report is to be published with the other reports in a volume to be edited by George Bermann.

$\dagger$ DOI 10.5131/AJCL.2013.0018 
defenses explicitly provided by the Convention: inability to present the case, lack of proper notice, lack of binding effect upon the parties, and violation of public policy. The Article also considers other defenses that arise out of application of the U.S. Constitution and federal rules of procedure: lack of personal jurisdiction and forum non conveniens. Finally, the Article distinguishes the circumstances that permit each of the following judicial dispositions: vacatur of arbitral award, enforcement or refusal to enforce arbitral award, and adjournment or stay of arbitral award.

\section{Implementation of the New York Convention in the UNITED STATES}

\section{A. Incorporation by Reference into the Federal Arbitration Act}

The New York Convention on Recognition and Enforcement of Foreign Arbitral Awards (hereafter "The New York Convention" or "The Convention") is a multilateral treaty that imposes dual enforcement obligations on the courts of contracting states. Specifically, these courts must enforce arbitration agreements involving international commerce and recognize and enforce arbitral awards made in other contracting states. ${ }^{1}$

The New York Convention resulted from an international conference convened in 1958 by the United Nations Economic and Social Council (ECOSOC). The United States delegation to the conference recommended that the United States not become a signatory to the New York Convention due to concerns that it would require substantial changes in state, and potentially even federal, court procedures. The United States' position changed as transnational commerce, transnational disputing and court costs increased. In 1970, the United States chose to ratify the treaty.

Congress implemented the Convention through incorporation by reference in Chapter 2 of the Federal Arbitration Act (hereafter FAA), which provides: "The Convention on the Recognition and Enforcement of Foreign Arbitral Awards of June 10, 1958, shall be enforced in United States courts in accordance with this chapter."

Chapter 2 also provides that the general provisions of Chapter 1 of the FAA apply to actions and proceedings brought under Chapter 2 , but only "to the extent that chapter [Chapter 1] is not in conflict with this chapter [Chapter 2] or the Convention as ratified by the United States."3

1. New York Convention, Art. I (1), Jun. 7, 1959, 330 U.N.T.S. 38 thereinafter New York Convention].

2. 9 U.S.C. $\$ 201(2012)$.

3. 9 U.S.C. $\$ 208(2012)$. 


\section{B. Dual Obligation of U.S. Courts to Recognize and Enforce Arbitration Agreements and Arbitral Awards}

As noted supra, Articles I and II of the Convention, as incorporated by the FAA, impose dual enforcement obligations upon the courts of the United States. In Lindo v. NCL (Bahamas), Ltd., ${ }^{4}$ The court described the procedures that parties must use to invoke these dual obligations:

To implement the Convention, Chapter 2 of the FAA provides two causes of action ... for a party seeking to enforce arbitration agreements covered by the Convention: (1) an action to compel arbitration in accord with the terms of the agreement, 9 U.S.C. $\$ 206$, and (2) at a later stage, an action to confirm an arbitral award made pursuant to an arbitration agreement, 9 U.S.C. $\$ 207.5$

It is noteworthy that the FAA imposes a three-year statute of limitations upon actions to confirm arbitral awards. ${ }^{6}$

\section{Foreign, Non-Domestic and Domestic Arbitral Awards}

The New York Convention is applicable to two types of awards: "foreign" and "non-domestic" awards. ${ }^{7}$ Foreign awards are those in which the arbitration was conducted in a seat outside United States territory. Even if the seat of the arbitration was within the United States, however, the FAA provides for the enforcement of an award that "involves property located abroad, envisages performance or enforcement abroad, or has some other reasonable relation with one or more foreign states." 8 Courts have interpreted the FAA to find that such awards are "non-domestic" and also governed by the Convention, even when one or both of the parties to the arbitration is domestic. ${ }^{9}$

4. Lindo v. NCL (Bahamas) Ltd., 652 F.3d 1257 (11th Cir. 2011) (citing to Czarina, L.L.C. v. W.F. Poe Syndicate, 358 F.3d 1286, 1290-91 (11th Cir. 2004)).

5. Id. at 1262-1263.

6. 9 U.S.C. $\$ 207$ (2012); see Verve Communications Pvt. Ltd. V. Software Intern., Inc., No. 11-1280 2011 WL 5508636 (D.N.J. Nov. 9, 2011).

7. New York Convention, supra note 1 at Article 1 ("This Convention shall apply to the recognition and enforcement of arbitral awards made in the territory of a State other than the State where the recognition and enforcement of such awards are sought, and arising out of differences between persons, whether physical or legal. It shall also apply to arbitral awards not considered as domestic awards in the State where their recognition and enforcement are sought.")

8. 9 U.S.C. $\$ 202(2012)$.

9. See e.g., Industrial Risk Insurers v. M.A.N. Gutehoffnungshutte v. Industrial Risk Insurers, 141 F.3d 1434, 1441 (11th Cir. 1998) (joining First, Second, Seventh and Ninth Circuits in holding that arbitration agreements and awards involving a non-domestic party are "non-domestic" even if the arbitration was conducted in the United States). 


\section{Reservations Made by the United States}

Article I of the Convention provides that it "shall apply to the recognition and enforcement of arbitral awards made in the territory of the state other than the state where the recognition and enforcement of such awards are sought [.]" Article I (3), however, provides for limitations upon this broad grant of authority by allowing ratifying states to make "reciprocity" and "commercial" reservations. Specifically, a ratifying state may: ". . . on the basis of reciprocity declare that it will apply the Convention to the recognition and enforcement of awards made only in the territory of another contracting State" 10 and, ". . . also declare that it will apply the Convention only to differences ... . which are considered commercial under the national law of the state making such declaration."11 The United States has adopted both of these reservations.

\section{E. Reciprocity Reservation}

United States courts use the location of an arbitration to determine whether they must enforce the award. ${ }^{12}$ Even if both parties are from non-contracting states, the award will be enforced within the United States as long as the arbitration was conducted in a contracting state. On the other hand, if both parties are from contracting states but the arbitration occurred in a non-contracting state, the courts in the United States will not enforce the award. ${ }^{13}$

\section{F. Commercial Reservation}

The commercial reservation allows ratifying states to limit enforcement of arbitral awards to cases involving legal relationships that are commercial. If an arbitral dispute arises out of any other relationship, then courts in states that have taken the reservation cannot grant enforcement of the award.

Courts in the United States have found that a relationship qualifies as commercial as long as it is "related to" commerce. ${ }^{14}$ Two companies' exchange of goods for payment represents a classic exam-

10. New York Convention, supra note 1 at Article I(3).

11. New York Convention, supra note 1 at Article II(2).

12. La Societe Nationale Pour La Recherche v. Shaheen Natural Res. Co., $585 \mathrm{~F}$. Supp 57 (S.D.N.Y. 1983); See also E.A.S.T., Inc. of Stamford v. M/V Alaia, 876 F.2d 1168 (5th Cir. 1989).

13. Jugometal v. Samincorp, Inc., 78 F.R.D. 504 (S.D.N.Y. 1978) (court enforced an arbitration award decided in France (a member country) between a Yugoslavian party (non-member state) and a wholly-owned subsidiary of a Panamanian company); see also Lander Co. v. MMP Invs., 107 F.3d 476 (7th Cir. Ill. 1997) (finding that because performance was to occur internationally, Convention also governed enforcement of arbitral award made in the U.S. and involving parties based in the U.S.).

14. Trans Chem. Ltd. v. China Nat'l Mach. Imp. \& Exp. Corp., 978 F. Supp. 266 (S.D. Tex. 1997). 
ple of a commercial transaction and therefore fits squarely within the bounds of the New York Convention. ${ }^{15}$ In Henry $v$. Murphy, ${ }^{16}$ however, there was neither a formal agreement nor a contract. ${ }^{17}$ Nonetheless, the broad language of the Convention (“. . . legal relationships, whether contractual or not, which are considered as commercial ...") allowed the court to consider a dispute arising out of the sale of stock to come within the terms of the New York Convention. ${ }^{18}$ In some instances, even an employer-employee relationship involving a limited fiduciary duty will be considered "commercial in nature," and thus come within the bounds of the Convention. ${ }^{19}$ For example, courts now consider seamen's employment contracts commercial relationships under Chapter 1 of the FAA. ${ }^{20}$ In Francisco $v$. $M / T$ Stolt Achievement, the court found that even if a plaintiff-employee's claim lacks a tie to commerce as required by a strict interpretation of the language of the New York Convention, the plaintiff is nonetheless obligated to arbitrate his claim pursuant to an agreement in his employment contract. ${ }^{21}$

At this point, it does not appear that United States courts have identified any types of cases as not arbitrable under the Convention due to the limitations imposed by the commercial reservation. ${ }^{22}$

15. Siderius, Inc. v. Compania de Acero Del Pacifico, S. A., 453 F. Supp. 22, 24 (S.D.N.Y. 1978)

15. See also Ledee v. Ceramiche Ragno, 528 F. Supp. 243, 245 (D.P.R. 1981) ("The complaint shows on its face that it involves a transaction involving foreign commerce. The dispute, as the one in Siderius v. Compania de Acero del Pacifico, 453 F. Supp. 22 (S.D.N.Y., 1978), arose out of classical commercial relationship, one involving the purchase and sale of goods by two corporations.").

16. Henry v. Murphy, 2002 U.S. Dist. LEXIS 227 (S.D.N.Y. Jan. 8, 2002).

17. Id.

18. Henry v. Murphy, 2002 U.S. Dist. LEXIS 227 (S.D.N.Y. Jan. 8, 2002), affdd, 2002 U.S. App. LEXIS 23199 (2d Cir. Nov. 6, 2002).

19. Faberge Int'l Inc. v. Di Pino, No. 23387N,1985 N.Y. App. Div. LEXIS 45265 (N.Y. App. Div. July 2, 1985).

20. Amizola v. Dolphin Shipowner, S.A., 354 F. Supp. 2d 689 (E.D. La 2004.); Bautista v. Star Cruises, 286 F. Supp. 2d 1352 (S.D. Fla. 2003), aff'd, 396 F.3d 1289 (11th Cir. 2005); Robbins v. Princess Cruise Lines, Ltd, CV 07-6088 GAF CTX, 2007 WL 4801296 (C.D. Cal. Nov. 5, 2007).

21. Francisco v. M/T Stolt Achievement, No. 00-3532 2001 U.S. Dist. LEXIS 3902 (E.D. La. Mar. 23, 2001) aff'd, 293 F.3d 270, 273-75 (5th Cir. 2002).

22. But see Arthur J. Gemmell, Commercial Arbitration in the Islamic Middle East, 5 Santa Clara J. Int'l L. 169, 187 (2006) (asserting that matters of family or inheritance law would come within the commercial reservation and that this would be "especially important to Middle Eastern Islamic states, where such matters are reserved exclusively to domestic jurisdiction"). 


\section{The Panama Convention-an Alternative Means of Enforcing an Arbitral Award}

The Inter-American Convention on International Commercial Arbitration $^{23}$ (herein Panama Convention) was signed in Panama in 1975 at a special conference of the Organization of American States (herein OAS) on private international law. ${ }^{24}$ Adopted by the United States and enacted through Chapter 3 of the FAA, ${ }^{25}$ the Convention has seventeen signatory nations located throughout the Americas. ${ }^{26}$

Unless the parties expressly agree otherwise, if a majority of the parties involved in an arbitration are citizens of Panama Convention ratifying or acceding states and these states also are OAS members, the Panama Convention will apply and, indeed, preempts the New York Convention. In all other international commercial arbitration matters, the New York Convention will apply. ${ }^{27}$

\section{Objections and Defenses to the Enforcement of Arbitration AgreEments}

Parties may raise both jurisdictional and non-jurisdictional objections to the enforcement of an arbitration agreement or clause.

\section{A. Challenges to the Jurisdiction of the Arbitrators}

The doctrine of competence-competence is the general understanding by international courts that arbitrators have the authority to examine their own jurisdiction without prior court approval to do so. ${ }^{28}$ In the United States, however, there is a presumption that a court will determine whether an arbitrator has jurisdiction to decide

23. The Inter-American Convention on International Commercial Arbitration, Jan. 30, 1975, 1438 U.N.T.S. 245 [hereinafter Panama Convention] available at http:/ /www.oas.org/juridico/english/treaties/b-35.html.

24. Found at http://www.oas.org/juridico/english/sigs/b-35.html.

25. 9 U.S.C. $\$ 301-307$ (2012).

26. Currently, Argentina, Bolivia, Brazil, Chile, Columbia, Costa Rica, Ecuador, El Salvador, Guatemala, Honduras, Mexico, Panama, Paraguay, Peru, the United States of America, Uruguay, and Venezuela are signatory nations. Of OAS memberstates, only the Dominican Republic and Nicaragua have not signed the Panama Convention. Organization of American States, Inter-American Convention on International Commercial Arbitration, (providing a list of signatories) available at http://www.oas.org/juridico/english/sigs/b-35.html.

27. See 9 U.S.C. $\$ 305$ (2012) ("When the requirements for application of both the Inter-American Convention and the Convention on the Recognition and Enforcement of Foreign Arbitral Awards of June 10, 1958, are met, determination as to which Convention applies shall, unless otherwise expressly agreed, be made as follows: (1) If a majority of the parties to the arbitration agreement are citizens of a State or States that have ratified or acceded to the Inter-American Convention and are member States of the Organization of American States, the Inter-American Convention shall apply. (2) In all other cases the Convention on the Recognition and Enforcement of Foreign Arbitral Awards of June 10, 1958, shall apply.").

28. Margaret Moses, The Principles and Practice of International CommerCial Arbitration, 91 (2008). 
a controversy. ${ }^{29}$ There is a further presumption in favor of finding that the arbitrator has such jurisdiction. ${ }^{30}$ Once the court finds that the arbitrator possesses jurisdiction and enforces the arbitration clause, the arbitrator or arbitral panel will decide substantive issues regarding the underlying contract and allegations of waiver, delay in bringing arbitration, and other similar contentions. ${ }^{31}$

\section{B. Severability of Arbitration Clause}

The Supreme Court in Buckeye Check Cashing v. Cardigna ${ }^{32}$ determined that there are two main classes of challenges to a contract containing an arbitration agreement: ${ }^{33}$ a challenge to the arbitration agreement itself and a challenge to the contract as a whole.

Under the FAA, arbitration clauses or agreements are "severable" from the contract as a whole. ${ }^{34}$ As a result, even if one of the parties challenges the legality of the overall contract, a court may nonetheless find the arbitration agreement enforceable. Questions regarding the substance of the underlying contract will then be within the jurisdiction of the arbitrator.

This "severability doctrine" has the practical effect of limiting the scope of a court's initial examination to the arbitration agreement itself. Even in instances in which there are allegations of fraud in the inducement of the contract, a court generally will not examine the substance of the controversy unless there is an allegation of fraud in the inducement of the arbitration clause.$^{35}$ Also, United States courts will decline to decide if an arbitration agreement is invalid unless the arbitration clause is specifically challenged by a party. ${ }^{36}$ Only in direct challenges of the arbitration agreement will a United States court remove the controversy from the arbitrator's discretion.

\section{Requirement of Signed Agreement in Writing}

In order to win enforcement of an arbitration agreement pursuant to the New York Convention, the requirements of the Convention must be met. ${ }^{37}$ One such requirement is the "agreement in writing" provision of Article II (2) of the Convention: "The term 'agreement in writing' shall include an arbitral clause in a contract or an arbitra-

\footnotetext{
29. First Options of Chicago v. Kaplan, 514 U.S. 938, 946 (1995).

30. Moses H. Cone Mem'l Hosp. v. Mercury Const. Corp., 460 U.S. 1, 24 (1983).

31. Id.

32. Buckeye Check Cashing v. Cardigna, 546 U.S.440 (2006).

33. Id. at $444-45$.

34. Id. at 445 .

35. Prima Paint Corp. v. Flood \& Conklin Mfg. Co., 388 U.S. 395, 403-404 (1967). 2008).

36. Advance Am. Servicing of Arkansas, Inc. v. McGinnis, 375 Ark. 24, 38 (Ark.

37. This can be understood as simply a matter of meeting statutory requirements, or as a matter of subject matter jurisdiction.
} 
tion agreement, signed by the parties or contained in an exchange of letters or telegrams." 38

In applying the requirement of a signed agreement in writing, American courts must sometimes determine the ability of signatories to bind non-signatories. This determination, in turn, can require choice of law analysis. In InterGen N.V. v. Grina ${ }^{39}$ the court held that an arbitration agreement was unenforceable against the parties because they were distinct corporate entities and had not signed the agreement. ${ }^{40}$ More recently, however, an American court held that an arbitration agreement might be enforceable against a corporate non-signatory, depending upon the application of English law to the issue of piercing the corporate veil. ${ }^{41}$ The signatories had specified English law in their choice of law provision in the agreement. In Iran Ministry of Defense of Islamic Republic of Iran v. Gould Inc. ${ }^{42}$ the Ninth Circuit also found that a federal district court had jurisdiction to enforce an arbitration award in favor of Iran against an American corporation even though there was no written arbitration agreement between the parties. The court found that the Convention's requirement of a signed written agreement was met by the execution of the Algiers Accord on behalf of private claimants and Iran.

There is a split among the federal circuit courts on whether a contract containing an arbitration clause-in contrast to a separate arbitration agreement-must be signed by the parties in order to make the agreement to arbitrate enforceable under the Convention. (The Supreme Court has declined to grant certiorari on this point."43) Jurisdictions typically use one of three approaches to handle the signature requirement. Courts using the first approach always require the signatures of the parties regardless of whether the case involves an arbitration clause contained in a primary contract or a separate

38. Intergen N.V. v. Grina, 344 F.3d 134, 141 (1st Cir. 2003). (citing Scherk v. Alberto-Culver Co., 417 U.S. 506, 520 n. 15 (1974)); New York Convention, supra note 1 at Article II(2).

39. $I d$.

40. The signatories in the InterGen case were corporations related to the parties, but were distinct entities. Without the signatures of the distinct entities who were parties to the dispute, the arbitration agreement was not enforceable by the parties. See id. at 150.

41. See FR 8 Singapore Pte. Ltd. V. Albacore Maritime Inc., 754 F. Supp. 2d 628 (S.D.N.Y. 2010).

42. Iran Ministry of Def. of Islamic Rep. of Iran v. Gould Inc., 887 F.2d 1357 (9th Cir. 1989).

43. See Nielson v. Seaboard Corp., 129 S. Ct. 624 (2008), cert. denied; Petition for Writ of Certiorari, Nielson v. Seaboard Corp., 08-65 2008 WL 2773349 at i (July 14, 2008) (stating the question presented was "the proper scope and application of article II(2) of the Convention, relating to when an arbitration clause must be 'signed by the parties or contained in an exchange of letters or telegrams"'). 
arbitration agreement. ${ }^{44}$ The second approach requires the signatures of the parties only when there is a separate arbitration agreement. ${ }^{45}$ This approach obligates a party who never signed the primary contract containing an arbitration clause to arbitrate, regardless of whether the primary contract has been found enforceable. Courts using the third approach explicitly reconcile the Convention's "signed by the parties" writing requirement with the FAA's requirement of only a "written provision" in the contract or arbitration "agreement in writing." 46 As noted supra, Chapter 2 of the FAA incorporates the Convention by reference, and then specifies that the "domestic arbitration" rules of Chapter 1 also apply unless they are in conflict with the provisions of Chapter 2. The FAA's deference to the Convention indicates that Article II(2) of the Convention will control regarding the signature requirement.

UNCITRAL has recommended that states adopt Article 7 of the UNCITRAL Model Law on International Commercial Arbitration as revised, which specifically recognizes that the writing requirement for arbitration agreements may be met by electronic communications including, but not limited to, electronic mail, telegram, telex or telecopy. ${ }^{47}$ At least one court in the United States has already found that a two-way exchange of emails meets the Convention's writing requirement. ${ }^{48}$

\section{Defense that the Agreement is Null and Void, Inoperative or Incapable of Being Performed}

Article II(3) of the New York Convention provides that a court "shall, at the request of one of the parties, refer the parties to arbitration, unless it finds that the said agreement is null and void, inoperative or incapable of being performed." The question of whether an agreement is "null and void" has been the most frequent subject of litigation, although there has also been one case interpret-

44. See Sarhank Grp. v. Oracle Corp., 404 F.3d 657, 660 n. 2 (2d Cir. 2005); Standard Bent Glass Corp. v. Glassrobots Oy, 333 F.3d 440, 449 (3d Cir. 2003); Kahn Lucas Lancaster, Inc. v. Lark Int'l Ltd., 186 F.3d 210 (2d Cir. 1999).

45. Sphere Drake Ins. PLC v. Marine Towing, Inc., 16 F.3d 666, 669 (5th Cir.1994)

46. See Sourcing Unlimited, Inc. v. Asimco Int'l, Inc., 526 F.3d 38 (1st Cir. 2008); Regent Seven Seas, Nos. 06-22347-CIV, 06-22539-CIV 2007 WL 601992 (S.D. Fla. Feb. 21, 2007); Sarhank, 404 F.3d at 660; Kahn Lucas Lancaster, 186 F.3d 210.

47. G.A. Res. 61/33, U.N. Doc. A/RES/61/33 (Dec. 18, 2006), available at http:// www.uncitral.org/pdf/english/texts/arbitration/NY-conv/a61-33-e.pdf; UNCITRAL Rep. on the work of its 39th Sess., June 19-July 6, 2006, U.N. GOAR, 61st Sess., Supp. No. 17, U.N. Doc. A/61/17 at 61, available at http://documents-dds-ny.un.org/doc/UNDOC/GEN/V06/558/15/pdf/V0655815.pdf?OpenElement [hereinafter 2006 UNCITRAL Recommendation].

48. Glencore Ltd. v. Degussa Engineered Carbons L.P., 848 F.Supp.2d 410 (S.D.N.Y. 2012) (finding that an exchange of emails going both ways was sufficient for the "agreement in writing" requirement). 
ing whether an agreement was "incapable of being performed." To date, no court in the United States has examined whether an agreement is "inoperative" under the Convention.

Even when the underlying contract contains a specific choice of law clause, courts will evaluate whether the arbitration clause is enforceable according to the law of the forum. In Freudensprung $v$. Offshore Technical Services, Inc. ${ }^{49}$ for example, the court ruled that American federal law applied despite the parties' choice of Texas law. According to the Freudensprung court, the FAA preempted any conflicting state law contained in the choice of law provision. The court referenced Matter of Ferrara S.p.A. ${ }^{50}$ which explained:

In actions arising under Chapter 1 of the Federal Arbitration Act (Act), questions concerning the enforceability of arbitration agreements are governed by federal law, even where the parties have by agreement specified the law governing the interpretation of the contract, and the place of and/or tribunal for arbitration .... This result is consistent in these cases with the view that enforceability of an agreement to arbitrate relates to the law of remedies and is therefore governed by the law of the forum. ${ }^{51}$

Under federal law then, the court in Freudensprung enforced the agreement to arbitrate due to the United States policy establishing a presumption of arbitrability. ${ }^{52}$

Apple \& Eve, LLC v. Yantai N. Andre Juice Co. ${ }^{53}$ involved parties' potential waiver of an arbitration agreement and a determination regarding whether such waiver made the agreement "null and void." In this case, the defendants had actively attempted to avoid arbitration until the last possible moment. The question was whether the defendants had therefore impliedly waived their right to arbitration. The arbitration clause specified the country of the defendant-China-as the seat of the arbitration, but did not include a choice of law provision. The Second Circuit used its own forum law to determine whether the defendants had waived their right to arbitration. The Second Circuit had long held that arbitration agreements, like other contract rights, could be modified or waived by the parties' actions. As such, the court found that the defendants here had waived their right to arbitration in China and therefore the agree-

49. Freudenspring v. Offshore Technical Serv., Inc., 379 F. 3d 327, n. 7 (5th Cir. 2004).

50. In re Ferrara S.p.A., 441 F. Supp. 778 (S.D.N.Y. 1977).

51. Id. at n. 2 (citations omitted).

52. Freudensprung, 379 F. $3 d$ at 341. 2009).

53. Apple \& Eve, LLC v. Yantai N. Andre Juice Co., 610 F. Supp. 2 d 226 (E.D.N.Y 
ment was considered "null and void" under the Convention. The court vacated an earlier order staying legal action pending arbitration. ${ }^{54}$

Some courts in the United States have found that an international standard represents the law of the forum that will be used to determine whether an arbitration clause is null and void. Specifically, in Bautistia v. Star Cruises, ${ }^{55}$ the court found that a contract could be found null and void under the Convention only in situations involving standard breach of contract claims "such as fraud, mistake, duress, and waiver-that can be applied neutrally on an international scale." 56 Bautistia was first overturned, then later upheld by subsequent cases in the 11th Circuit. ${ }^{57}$

In Corcoran v. Ardra Ins. Co., Ltd., 58 the court dealt with whether the arbitration clause was "incapable of being performed." In the absence of a choice of law provision and in light of the international nature of the agreement, the court concluded that the Convention applied. The court determined that the law of New York applied, and such law did not permit a liquidator who had been appointed to oversee an insolvency to participate in arbitration. Therefore, the arbitration clause was "incapable of being performed,"59 the claims were not "capable of settlement by arbitration,"60 and the court could not compel arbitration. ${ }^{61}$ The court noted that the "practical result" was "to relieve the parties from having to proceed through a futile arbitration in which the resulting award would be unenforceable in New York because of the Supreme Court's exclusive jurisdiction in liquidation matters." 62

54. Id. at 234.

55. Bautistia v. Star Cruises, 396 F.3d 1289 (11th Cir. 2005).

56. Id. at 1302 (quoting DiMercurio v. Sphere Drake Ins. PLC, 202 F.3d 71, 80 (1st Cir.2000)) (refusing to find agreement null and void on unconscionability grounds).

57. See Thomas v. Carnival Corp., 573 F.3d 1113 (11th Cir. 2009) (refusing to enforce arbitration agreement contained in a seamen employment contract because while the NY Convention does apply, the affirmative defense of violation of public policy permitted the court to not enforce the clause; here the court determined that compelling foreign arbitration that would follow foreign law is adverse to the public policy of the United States); Lindo v. NCL (Bahamas) Ltd., 652 F.3d 1257 (11th Cir. 2011) (resolving the intra-circuit split generated by Thomas by following the reasoning in Bautistia and limiting the null and void affirmative defense to bases that would be internationally recognized).

58. Corcoran v. Ardra Ins. Co., Ltd., 77 N.Y.2d 225 (N.Y. 1990).

59. New York Convention, supra note 1, at Article II, II 3.

60. New York Convention, supra note 1, at Article II, II 1.

61. Corcoran v. Ardra Ins. Co., Ltd., 77 N.Y.2d at 232-233.

62. Id. at 233 . 


\section{E. Waiver of the Right to Arbitrate}

Like many other contractual obligations, the right to arbitrate is waiveable. ${ }^{63}$ If a party has waived his or her right to arbitrate, the party who would have been entitled to have a dispute resolved through arbitration cannot later argue that the issue should have been decided in that forum. The party who could have argued against arbitration is in default.

A party is able to waive his or her right to arbitrate in two ways: by expressly indicating a desire to resolve the relevant claims before a United States court rather than through arbitration, or by engaging in civil litigation so that the other party will be prejudiced if the case is transferred to arbitration. ${ }^{64}$ A court may find prejudice-and waiver of the right to arbitrate-if "the party seeking arbitration allows the opposing party to undergo the types of litigation expenses that arbitration was designed to alleviate." 65 On the other hand, if litigation is in its early stages, it is unlikely a court will find that initiating a lawsuit is inconsistent with an intent to arbitrate. ${ }^{66}$

\section{F. Lack of Knowledge that an Arbitration Clause Exists}

Under United States law, an arbitration provision usually is upheld and enforced even if the party disputing the clause asserts that he or she did not read the clause. ${ }^{67}$ This is true even if the agreement would not be enforceable in the nation of the disputing party, particularly if the parties have chosen United States law to govern arbitrable disputes. ${ }^{68}$ A party seeking to avoid enforcement of an arbitration clause must make a showing sufficient to come within one of the exceptions to the general rule that a person of ordinary understanding and competence is bound by the provisions of a contract he signed regardless of whether or not he has read such provisions. ${ }^{69}$

63. See Cornell \& Co., Inc. v. Barber \& Ross Co., 360 F.2d 512, 513 (D.C.Cir. 1966); see also Apple \& Eve, LLC v. Yantai N. Andre Juice Co., 610 F. Supp.2d 226, 228 (E.D.N.Y 2009).

64. Apple \& Eve, LLC., 610 F. Supp.2d at 228.

65. Morewitz v. W. of Eng. Ship Owners Mut. Prot. \& Indemnity Assoc. (Luxembourg), 62 F.3d 1356, 1366 (11th Cir. 1995).

66. Hodgson v. Royal Caribbean Cruises, Ltd., 706 F. Supp. 2d 1248, 1258 (S.D. Fla. 2009).

67. In re Ferrara S. p. A., 441 F. Supp. 778, 781-782 (S.D.N.Y. 1977).

68. Id.

69. Id at 782 . 


\section{Objections And Defenses To The Enforcement Of Arbitral Awards}

\section{A. Distinguishing Between Vacatur and Refusal to Enforce Arbitral Awards}

Although the focus of this Article is on American courts' enforcement or refusal to enforce arbitral awards, it is important to distinguish these from vacatur. According to American courts, the state in which an arbitral award is made has "primary" jurisdiction, and a court located in that state is free to vacate, annul or set aside an award in accordance with the state's domestic scheme of arbitral law "and its full panoply of express and implied grounds of relief."70 Thus, if an arbitration occurred in the United States-or, in some circumstances, under American law-American courts have primary jurisdiction and may apply the FAA's grounds for vacatur. ${ }^{71}$

In contrast, if an arbitral award was rendered in a foreign state, an American court has only "secondary" jurisdiction and may only decide whether to enforce, or refuse to enforce, the arbitral award. The court's review is then generally limited to the seven grounds provided in Article $\mathrm{V}$ of the New York Convention, infra. ${ }^{72}$

\section{B. Choice of Procedural Law for Judicial Review of an Arbitral Award}

Procedural law governs the arbitration proceeding; substantive law governs the interpretation of the underlying contract. ${ }^{73}$ American courts have found that an agreement specifying the place or seat of the arbitration creates a strong presumption that the procedural law of that state applies to the arbitration. ${ }^{74}$ A party who fails to make the necessary showings will not be able to overcome such presumption. ${ }^{75}$

Although it is possible for the seat of an arbitration to be in one state while the proceedings will be held under the arbitration law of

70. Yusuf Ahmed Alghanim v. Toys "R" Us, 126 F.3d 15, 23 (2d Cir. 1997); see Karaha Bodas Co., LLC v. Perusahaan Pertambangan Minyak Dan Gas Bumi Nnegara, 364 F. 3d 274, 287-88 (5th Cir. 2004); M\&C Corp. v. Erwin Behr GmbH, 87 F.3d 844,849 (6th Cir. 1996).

71. See Yusuf Ahmed, 126 F.3d at 21-23; Ario v. Underwriting Members of Syndicate, 618 F.3d 277 (3d Cir. 2010).

72. See Yusuf Ahmed, 126 F.3d at 21-23; Karaha Bodas Co., 364 F. 3d at 287-88.

73. See M\&C Corp. v. Erwin Behr GmbH, 87 F.3d 844, 847-48 (6th Cir. 1996)

74. See Steel Corp. of the Philippines v. International Steel Services, Inc., 354 Fed. Appx. 689, 692-93 (3d Cir. 2009).

75. Karaha Bodas Co., 364 F. 3d at 287-88; See also Steel Corp. of the Philippines v. Int'l Steel Services, Inc., 354 Fed.Appx. 689, 694-94 (3d Cir. 2009) (finding that contractual provision that "enforcement" would be governed by Philippine law, rather than specific invocation of Philippine "procedural law," was insufficient to rebut the strong presumption in favor of the application of the procedural law of the place of the arbitration). 
another state, American courts have approvingly referenced authorities describing this practice as "exceptional," "almost unknown," and "a possibility that is more theoretical than real."76 American courts have also discussed concerns regarding the complexity, inconvenience and challenges to forum neutrality created by requiring the arbitral panel seated in one state to interpret and apply the procedural law of another state. ${ }^{77}$

Some American courts have been required to grapple with application of the procedural law of individual American states rather than a national procedural law. The Third Circuit has found that parties may elect to be bound by individual American states' vacatur standards, rather than those contained in the FAA, ${ }^{78}$ because the FAA requires the enforcement of parties' agreements to arbitrate and does not bar the enforcement of state law rules. Importantly, however, "[i]t is federal law that allows the parties to make and enforce agreements that fall under the FAA or the Convention."79 The Third Circuit conditioned parties' ability to elect state law vacatur standards upon the expression of clear and specific intent to be bound by such standards. ${ }^{80}$

\section{Defenses to Enforcement of Arbitral Awards, Generally}

The FAA provides that if a court has jurisdiction under Chapter 2 , the court "shall confirm" an arbitral award "unless it finds one of the grounds for refusal or deferral of recognition or enforcement of the award specified in the said [New York] Convention."81 Article $\mathrm{V}(1)$ of the Convention permits a court to refuse to recognize and enforce an award if the protesting party furnishes proof that:

(a) The parties to the agreement referred to in [A]rticle II were, under the law applicable to them, under some incapacity, or the said agreement is not valid under the law to which the parties have subjected it or, failing any indication thereon, under the law of the country where the award was made; or

(b) The party against whom the award is invoked was not given proper notice of the appointment of the arbitrator or of

76. See Karaha Bodas Co., 364 F.3d at 291.

77. See id.

78. Ario v. Underwriting Members of Syndicate, 618 F.3d 277 (3d Cir. 2010).

79. Id.; See also Hall St. Assocs., LLC v. Mattel, Inc., 552 U.S. 576, 590 (2008) ("The FAA is not the only way into court for parties wanting review of arbitration awards: they may contemplate enforcement under state statutory or common law, for example, where judicial review of different scope is arguable").

80. See Ario, 618 F.3d at 290-95 (finding that when the arbitration provisions evidences only the parties' intent to be bound by state law regarding the conduct of the arbitration, the complaining party had not met its burden in demonstrating a clear intent to use state law to determine enforcement of the arbitral award).

81. 9 U.S.C. $\$ 207(2012)$. 
the arbitration proceedings or was otherwise unable to present his case; or

(c) The award deals with a difference not contemplated by or not falling within the terms of the submission to arbitration, or it contains decisions on matters beyond the scope of the submission to arbitration, provided that, if the decisions on matters submitted to arbitration can be separated from those not so submitted, that part of the award which contains decisions on matters submitted to arbitration may be recognized and enforced; or

(d) The composition of the arbitral authority or the arbitral procedure was not in accordance with the agreement of the parties, or, failing such agreement, was not in accordance with the law of the country where the arbitration took place; or

(e) The award has not yet become binding on the parties, or has been set aside or suspended by a competent authority of the country in which, or under the law of which, that award was made. ${ }^{82}$

In addition, Article $\mathrm{V}(2)$ permits a court to refuse to recognize and enforce an arbitral award if it finds that " $[t]$ he subject matter of the difference is not capable of settlement by arbitration under the law of that country" or "[t]he recognition or enforcement of the award would be contrary to the public policy of that country." 83 American courts have held that the complaining party bears a heavy burden to prove that one of the Convention's seven defenses applies. ${ }^{84}$

\section{Inability to Present Case and Lack of Proper Notice}

Article $\mathrm{V}(1)(\mathrm{b})$ of the Convention provides that a court may refuse to enforce an arbitral award if "[ $t]$ he party against whom the award is invoked was not given proper notice of the appointment of the arbitrator or of the arbitration proceedings or was otherwise unable to present his case." 85 American courts have found that the FAA's standards also apply in this context to the extent that they are "not in conflict" with those in the Convention. ${ }^{86}$ The FAA provides that a court may vacate an arbitral award "where the arbitrators were guilty of misconduct ... in refusing to hear evidence pertinent and

82. New York Convention, supra note 1, at Art. V (1).

83. New York Convention, supra note 1, at Art. V (2).

84. See e.g., Telenor Mobile Commc'n v. Storm L.L.C., 584 F.3d 396, 405 (2d Cir. 2009).

85. New York Convention, supra note 1 , at Article V(1)(b).

86. 9 U.S.C. $\$ 208$ (2012); Zeiler v. Deitsch, 500 F3d 157, 164 (2d Cir. 2007). 
material to the controversy; or of any other misbehavior by which the rights of any party have been prejudiced." 87

Courts in the United States have recognized that the defenses of lack of notice and inability to present the case essentially permit application of the forum state's standards of due process and, indeed, such due process rights are entitled to full force under the Convention. In the United States, the sources of such due process standards are the Due Process Clauses contained in the Fifth and Fourteenth Amendments, which generally provide that the state (both national and local) may not deprive a person of life, liberty or property without due process of law.

As American courts review arbitral awards, they cite frequently to the seminal case of Mathews $v$. Eldridge $e^{88}$ for the general rule that "the fundamental requirement of due process is the opportunity to be heard 'at a meaningful time and in a meaningful manner." 89 Interestingly, and somewhat confusingly, they do not cite to the more concrete three-part balancing test also established in Mathews for determining whether a procedure sufficiently meets the guarantee of procedural due process. ${ }^{90}$ American courts reviewing arbitral awards instead tend to observe only that due process requires an arbitral hearing to meet "the minimal requirements of fairness'-adequate notice, a hearing on the evidence, and an impartial decision by the arbitrator."91

87. 9 U.S.C. $\$ 10(a)(3)(2012)$.

88. Mathews v. Eldridge, 424 U.S. 319, 96 S.Ct. 893, 47 L.Ed.2d 18 (1976). (involving governmental deprivation of a citizen's benefits without first providing a pretermination in-person proceeding and finding that under the circumstances presented, the citizen was not entitled to such pre-termination in-person proceeding); see also Goldberg v. Kelly, 397 U.S. 254 (1970) (interpreting Due Process Clause to require procedures to be tailored to "the capacities and circumstances of those who are to be heard").

89. Mathews v. Eldridge, 424 U.S. 319, 333, 96 S.Ct. 893, 902, 47 L.Ed.2d 18 (1976), (quoting Armstrong v. Manzo, 380 U.S. 545, 552, 85 S.Ct. 1187, 1191, 14 L.Ed.2d 62 (1965)).

90. Id. at 335. This test requires a court to examine the significance of the private interest that is subject to deprivation, the governmental interest in achieving its public purposes effectively and efficiently through summary procedures, and the degree of risk that such procedures could result in erroneous deprivation. United States courts have regularly applied this test to determine the constitutionality of a wide variety of procedures involving the deprivation of life, liberty or property, while also recognizing that the right to due process does not require provision of the complete set of procedural rights guaranteed by the Federal Rules of Civil Procedure.

91. Karaha Bodas Co., at 298-299 (quoting Slaney v. Int'l Amateur Athletic Fed'n, 244 F.3d 580, 592 (7th Cir. 2001) which was quoting Sunshine Mining Co. v. United Steelworkers, 823 F.2d 1289, 1295 (9th Cir. 1987); Generica, 125 F.3d at 1130 (quoting same). See also Iran Aircraft Industries v. AVCO Corporation, 980 F.2d 141 (2d Cir. 1992), where the second circuit concluded that an arbitral panel had violated due process when it met with one of the parties on an ex parte basis during a pre-hearing conference, directed the party to submit audited summaries of invoice information rather than the invoices themselves, and then ruled against the party for its failure to submit invoices. 
Issues raised under Article $\mathrm{V}(1)(\mathrm{b})$ generally involve the unavailability of witnesses, the manner in which arbitrators heard offered evidence, and notice. When a witness was unavailable for an arbitration hearing, American courts examine whether the witness was essential, and whether the witness' testimony (or other evidence) could have been offered in other forms. ${ }^{92}$ Importantly, courts do not require arbitrators to hear all of the evidence offered by parties. They have noted that "the inability to produce one's witnesses before an arbitral tribunal is a risk inherent in an agreement to submit to arbitration" and that "by agreeing to arbitration, a party relinquishes his courtroom rights, included that to subpoena witnesses."93 As a result, American courts rarely refuse to enforce an arbitral award due to a party's inability to present his case as he or she wished or due to insufficient notice. ${ }^{94}$

\section{E. Lack of Binding Effect upon the Parties}

A court may refuse to enforce an arbitral award if it "has not yet become binding upon the parties."95 The party seeking to avoid enforcement on this basis has the burden of proving that an award is not binding. Courts similarly interpret the FAA to find a presumption

92. See, e.g. Abu Dhabi Inv. Auth. v. Citigroup, No. 12 Civ. 283(GBD) 2013 WL789642, n. 13 (S.D.N.Y. 2013); Tempo Shain Corp. v. Bertek, Inc., 120 F.3d 16 (2nd Cir. 1997) (vacating district court's confirmation of arbitral award and remanding for further consideration after finding that arbitral panel had refused to hear testimony from one witness who could testify regarding facts that only he could know); Karaha Bodas Co., LLC v. Perusahaan Pertambangan Minyak Dan Gas Bumi Nnegara, 364 F. 3d 274 (5th Cir. 2004); Parsons \& Whittemore Overseas Co., Inc. v. Societe Generale de L'Industrie Du Papier (RAKTA), 508 F.2d 969 (2d Cir. 1974); Sonera Holding, B.V. v. Cukurova Holding A.S., No. 11 Civ. 8909 (DLC) 2012 WL 3925853 (S.D.N.Y. 2012); Rive, S.A. v. Briggs of Cancun, Inc., 82 Fed. Appx. 359 (5th Cir. 2003); Libanco v. Rep. of Turkey; Generica, Ltd. v. Pharmaceutical Basics, Inc., 125 F.3d 1123 (7th Cir. 1997).

93. See generally, Parsons \& Whittemore Overseas Co., Inc. v. Societe Generale de L'Industrie Du Papier (RAKTA), 508 F.2d 969 (2d Cir. 1974); see also Karaha Bodas Co., L.L.C. v. Perusahaan Pertambangan Minyak Dan Gas Bumi Negara, 364 F.3d 274, 302 (5th Cir. 2004) (constitutional guarantee of procedural due process not violated even though a witness' misleadingly non-committal answer to arbitrator's question was found to be contradicted by later discovery of evidence that arbitral panel refused to admit); but see Iran Aircraft Industries v. AVCO Corporation, 980 F.2d 141 (2d Cir. 1992) (arbitral panel violated due process when it met with one of the parties on an ex parte basis during a pre-hearing conference, directed the party to submit audited summaries of invoice information rather than invoices themselves, and then ruled against the party for its failure to submit the invoices).

94. Mullane v. Central Hanover Bank \& Trust Co., 339 U.S. 306, provides the standard of notice, and courts generally find that notice meets this requirement. However, see Sea Hope Navigation Inc., v. Novel Commodities, S.A., No. 13 Civ. 32252013 WL 5695955 (S.D.N.Y. Oct. 21, 2013), where the court denied a motion of default judgment after the defendant asserted insufficient notice because it was notified via a generic email address that was not actively monitored by the company.

95. New York Convention, supra note 1 at Article V, III 1, e. 
that arbitral awards are binding. ${ }^{96}$ In order to win vacatur of an arbitral award from a reviewing court, the FAA requires the party contesting the award to bear the burden of proving that: “. . . the arbitrators exceeded their powers, or so imperfectly executed them that a mutual, final, and definite award upon the subject matter submitted was not made." 97

Thus, in order to be reviewable, enforceable and not subject to vacatur, the arbitral award must be both binding upon the parties and "mutual, final, and definite." In determining reviewability, American courts generally have focused on two of these requirements-finality and whether the award is binding. ${ }^{98}$

In applying these requirements to interim rulings, courts have generally refused to rely on the captioning of the ruling.99 Rather, courts examine the substance and effect of the interim award. Focusing on the FAA's finality requirement for enforceability, courts often analyze whether the ruling is "necessary to make the potential final award meaningful."100 Arbitrators' provisional awards designed to secure the effectiveness of the arbitration process are final and thus reviewable. ${ }^{101}$ In Pacific Reins. Mgmt. Corp. v. Ohio Reinsurance Corp. ${ }^{102}$ for example, the court affirmed the lower court's confirmation of an interim award establishing an escrow account, noting that temporary equitable awards can be "essential to preserve the integrity of that [the arbitral] process"103 and necessary to preserve assets or compel the performance that will make a final award meaningful. ${ }^{104}$ Similarly, in Island Creek Coal Sales v. City of Gainesville,

96. See Chromalloy Aeroservices v. Arab Rep. of Egypt, 939 F. Supp. 907, 910 (D.D.C. 1996); see also Europcar Italia v. Maiellano Tours, Inc., 156 F.3d 310, 314 (2d Cir. 1998) (examining the effect of Italian arbitrato irrituale and distinguishing an award that is "binding on the parties" from an award that is "judicially binding").

97. 9 U.S.C. $\S 10(a)(4)$ (West 2012).

98. See New United Motor Mfg., Inc. v. United Auto Workers Local, 617 F.Supp.2d 948, 954 (N.D.Cal. 2008) (citing ConnTech Dev. Co. v. Univ. of Conn. Educ. Prop., Inc., 102 F.3d 677, 686 (2nd Cir.1996)); Millmen Local 550, United Broth. of Carpenters and Joiners of Am., AFL-CIO v. Wells Exterior Trim, 828 F.2d 1373 (9th Cir.1987)

99. Publicis Commc'n v. True N. Commc'ns, Inc., 206 F.3d 725, 728 (7th Cir.2000); see Pac. Reins. Mgmt. Corp. v. Ohio Rein. Corp., 935 F.2d 1019, 1030 (9th Cir.1991). ("finality should be judged by substance and effect, not by superficial technicalities.").

100. Publicis Commc'n v. True N. Commc'ns, Inc., 206 F.3d at 729; see also Yasuda Fire \& Marine Ins. Co. of Europe v. Continental Cas. Co., 37 F.3d 345 (7th Cir. 1994), Pac. Reins. Mgmt. Corp. v. Ohio Rein. Corp., 935 F.2d at 1023.

101. Certain Underwriters at Lloyd's, London v. Argonaut Ins. Co., 264 F. Supp. 2d 926, 937 (N.D. Ca. 2003); Sojitz Corp. v. Prithvi Info. Solutions Ltd., 921 N.Y.S.2d 14 (N.Y. App. Div. 2011) (also referencing New York statute authorizing attachment to permit securing finality of arbitral award).

102. Pacific Reins. Mgmt. Corp. v. Ohio Reinsurance Corp., 935 F.2d 1019 (9th Cir. 1991).

103. Id. at 1023 (but vacating the confirmation as to one party).

104. Id. 
Florida, ${ }^{105}$ the appellate court affirmed the district court's refusal to vacate an interim award requiring specific performance of a contract until the final award was determined, because such performance ensured that no further harm would come to the contractual relationship if the award was upheld. ${ }^{106}$ Courts have diverged in determining whether interim arbitral orders permitting class certification are sufficiently final to be subject to judicial review. ${ }^{107}$

In contrast, when courts' analysis of an arbitrator's intent reveals that he did not intend an interim measure to be final or intended it to be subject to modification, courts have found that the award was not sufficiently final to be reviewable. In Chinmax Med. Sys. Inc. v. Alere San Diego, Inc. ${ }^{108}$ for example, an "emergency arbitrator" had issued an order providing for temporary equitable relief that required one of the parties to take certain actions within ten days. The interim order also provided, however, that it was being issued to facilitate consideration "by the full panel of conservancy ....'" and was subject to review by "the full arbitration tribunal, once appointed, and thereafter as the tribunal may order." Finally, the rules of the arbitral organization explicitly provided for reconsideration, modification or vacatur of the interim award once the tribunal was constituted. ${ }^{109}$ Under all of the circumstances presented, the court concluded that the order was not final. In other contexts, when an arbitrator has retained jurisdiction to make a later modification of a substantive order, United States courts have similarly focused on the arbitrator's intent to conclude that the order does not represent a final award. ${ }^{110}$ Generally, when arbitrators make interim rulings that do not resolve the merits of the claim submitted to them, judicial review is exceptional. ${ }^{111}$

105. Island Creek Coal Sales v. City of Gainesville, Fla., 729 F.2d 1046 (6th Cir. 1984) (abrogated on other grounds, in Cortez Byrd Chips v. Bill Harbert Constr., 529 U.S. $193(2000))$.

106. Id. at 1049 .

107. Compare Marron v. Snap-On Tools, Co., No. 03-4563, 2006 U.S. Dist. LEXIS 523 (D.N.J. Jan. 9, 2006) with Genus Credit Mgmt. Corp. v. Jones, No. JFM-05-3028, 2006 U.S. Dist. LEXIS 16933, at 4 (D. Md. April 6, 2006).

108. Chinmax Med. Sys. Inc. v. Alere San Diego, Inc.,10CV2467 WQH NLS, 2011 WL 2135350 (S.D. Cal. May 27, 2011).

109. Id. at 5 .

110. Orion Pictures Corp. v. Writers Guild of Am., W., Inc., 946 F.2d 722, 724 (9th Cir.1991) (interpreting the Labor Management Relations Act rather than the FAA; finality requires that arbitrator must intend the arbitration award to be a "complete determination of every issue submitted").

111. Quixtar Inc. v. Brady, 2008 WL 5386774 at 13 (E.D. Mich. Dec. 17, 2008) (quoting Michaels v. Mariforum Shipping, S.A., 624 F.2d 411, 414 (2d Cir. 1980)). Although there is no case law directly on point, it appears that advisory awards are unlikely to be entitled to judicial review. See Hoffman La Roche v. Qiagen 730 F.Supp.2d 318, 328 (S.D.N.Y 2010) (reasoning that an arbitral award is entitled to deference because, "an arbitration panel's conclusions are more than advisory opinions for the federal courts-rather, they are thoughtful analyses made by adjudicators steeped in the facts and law"). 


\section{F. Violation of Public Policy}

Article V(2)(b) of the New York Convention provides that a court may refuse to enforce an arbitral award "if the competent authority in the country where recognition and enforcement is sought finds that ... [t]he recognition or enforcement of the award would be contrary to the public policy of that country."112

Due to the "general pro-enforcement bias informing the Convention" and international considerations of reciprocity, ${ }^{113}$ American courts have construed the public policy exception very narrowly. Specifically, courts have concluded that they should deny enforcement of an award only when such enforcement would violate the United States' "most basic notions of morality and justice[,]"114 be "repugnant to fundamental notions of what is decent and just" 115 in the United States, or "the contract as interpreted [by the arbitrators] would violate some explicit public policy that is well defined and dominant and is ascertained by reference to the laws and legal precedents and not from general consideration of supposed public interests."116

The public policy exception also may preclude enforcement if the arbitral award or arbitral agreement ${ }^{117}$ was fraudulently obtained. This determination is distinct from the issue of whether the primary agreement was forged or fraudulently induced. The latter determination is to be made by the arbitral panel and cannot be re-litigated before the court during confirmation or enforcement proceedings. ${ }^{118}$ Specifically, American courts have held that they may refuse enforce-

112. New York Convention, supra note 1 at Article V(2)(b).

113. Parsons \& Whittemore Overseas v. Societe Generale De Lindustrie Du Papier 508 F.2d at $973-74$.

114. See Fotochrome, Inc. v. Copal Co., 517 F.2d 512, 516 (2d Cir. 1975); Rive v. Briggs of Cancun, 82 Fed.Appx. 359, 364 (5th Cir. 2003); Karaha Bodas Co., LLC v. Perusahaan Pertambangan Minyak Dan Gas Bumi Negara, 364 F.3d 274, 306 (5th cir. 2004); Parsons \& Whittemore Overseas v. Societe Generale De Lindustrie Du Papier, 508 F.2d 969, 974 (2nd Cir. 1974); Agility Pub. Warehousing Co. K.S.C., Prof'l Contract Adm'rs, Inc.v. Supreme Foodservice GmbH, 495 Fed.Appx. 149, 152 (2d Cir. 2012).

115. Rep. of Argentina v. GB Group PLC, 764 F. Supp.2d 21, 39 (D.C. 2011) (quoting Ackerman v. Levine, 788 F.2d 830, 841 (2d Cir. 1986) and Tahan v. Hodgson, 662 F.2d 862, 864 (D.C.Cir.1981)).

116. Banco de Seguros del Estado v. Mut. Marine Office, Inc., 344 F.3d 255, 264 (2d Cir. 2003) (alteration in original) (quoting United Paperworkers Int'l Union v. Misco, Inc., 484 U.S. 29 (1987)); W.R. Grace \& Co. v. Rubber Workers, 461 U.S. 757, 766 (1983); Indus. Risk Insurers v. M.A.N. Gutehoffnungshutte v. Indus. Risk Insurers, 141 F.3d 1434, 1445 (11th Cir. 1998); Rep. of Argentina v. GB Grp. PLC, 764 F. Supp.2d at 31.

117. See China Minmetals Materials Imp. \& Exp. Co., Ltd. v. Chi Mei Corp., 334 F.3d 274, 289-90, n. 12 (3d Cir. 2003) (because one of the parties claimed forgery of the signatures on the agreements containing arbitration clauses, Third Circuit vacated enforcement order of the district court and remanded for court to determine whether parties had reached a valid agreement to arbitrate; the court specifically expressed no opinion regarding the applicability of Article $\mathrm{V}(2)(\mathrm{b}))$.

118. See Europcar Italia v. Maiellano Tours, Inc., 156 F.3d 310, 315 (2d Cir. 1998). 
ment under the public policy exception if they find that the prevailing party furnished perjured evidence to the arbitral tribunal or the award was procured by fraud. ${ }^{119}$

The language of Article $\mathrm{V}(2)(\mathrm{b})$ makes it clear that the exception is meant to accommodate the public policy of the local forum in which enforcement is sought, rather than international public policy. ${ }^{120}$ In a country with a federalist governmental system such as the United States, however, the language of the exception could invite use of either national public policy, or public policy as determined by individual states. American courts have generally required use of national public policy.121 Changzhou Amec Eastern Tools, however, reveals the complex relationship between national and state law in the United States. There, in the course of deciding whether Article $\mathrm{V}(2)(\mathrm{b})$ permitted the refusal to enforce an arbitral award, the district court found that national arbitration law required the application of California contract law regarding the defense of duress. ${ }^{122}$ Thus, in that instance, the court found that national public policy incorporated the law of an individual state.

\section{G. Lack of Personal Jurisdiction}

The New York Convention does not specifically list lack of personal jurisdiction as a valid defense to enforcement. Article III of the Convention provides that contracting states shall recognize and enforce arbitral awards "in accordance with the rules of procedure of the territory where the award is relied upon[,]"123 and some commentators have suggested that the requirement of personal jurisdiction can be understood to represent such a rule of procedure. ${ }^{124}$

119. See Karaha Bodas Co., L.L.C. v. Perusahaan Pertambangan Minyak Dan Gas Bumi Negara, 364 F.3d 274, 306 (5th Cir. 2004).

120. Some commentators have derided this choice as "regrettable." See Hans Smit, Comment on Public Policy in International Arbitration, 13 Am. Rev. InT'L ARB. 65 (2002) (cited in Linda J. Silberman, Civil Procedure Meets International Arbitration: A Tribute to Hans Smit, 23 Am. Rev. InT'L ARB. 439, 447 (2012)).

121. Agility Public Warehousing Co. K.S.C., Professional Contract Administrators, Inc. v. Supreme Foodservice GMBH, 495 Fed.Appx. 149, 152 (2d Cir. 2012) (Second Circuit found that the requirements of the Convention's public policy exception were not met by a New York public policy requiring the dismissal of a plaintiff's claim if the plaintiff (or a principal of the plaintiff corporation) invokes a privilege and refuses to testify; here, employees had refused to testify after recent unsealing of indictment against their employer).

122. Changzhou Amec E. Tools and Equip. Co. v. E. Tools \& Equip., No. EDCV 1100354 VAP 2012 WL 3106620 at 13 (C.D. Cal. July 30, 2012).

123. New York Convention, supra note 1 at Article III.

124. See Ank A. Santens, Difficulties Enforcing New York Convention Awards in the U.S. Against Non-U.S. Defendants: Is the Culprit Jurisprudence on Jurisdiction, the Three-Year Time Bar in the Federal Arbitration Act, or Both?, Kluwer Arbitration Blog, (Dec. 23, 2009), http://kluwerarbitrationblog.com/blog/2009/12/23/difficulties-enforcing-new-york-convention-awards-in-the-us-against-non-us-defendants-is-theculprit-jurisprudence-on-jurisdiction-the-three-year-time-bar-in-the-federal-arbitration-act-or-bot/ (citing as analogous, but not endorsing, Monegasque de Reassurances 
In general, though, courts in the United States have not tended to rely on the language of the Convention to permit examination of personal jurisdiction. Rather, they have turned to the individual forum state's long-arm statute ${ }^{125}$ and the Due Process Clause described supra. An American court's judgment is void if the court lacks personal jurisdiction over the defendant, and the defendant did not waive this constitutional defense.

Obviously, courts may assert personal jurisdiction over a defendant who is a citizen of the state in which the court is located ("forum state") or over a defendant whose property is at issue and is located in the forum state. ${ }^{126}$ It is also relatively straightforward that courts in the United States may assert personal jurisdiction over a defendant who was served with notice of process while in the forum state $^{127}$ or has such significant and regular contacts with the forum state that courts have "general jurisdiction" over him or her. ${ }^{128}$ Thus, personal jurisdiction generally will not be an issue in the enforcement of foreign arbitral awards in the United States because the award debtor is likely to be located in the forum state, served while in the forum state, possess property in the forum state, or have very significant and regular contacts with the forum state. American courts also have been willing to find award debtors subject to personal jurisdiction based on the contacts that their affiliates have with the forum state, ${ }^{129}$ but it appears that the U.S. Supreme Court is narrowing this basis for general jurisdiction. ${ }^{130}$

S.A.M. v. NAK Naftogaz of Ukraine, 311 F.3d 488 (2d Cir. 2002) (finding that the doctrine of forum non conveniens was applicable as a "rule of procedure" under Article III of the New York Convention); Aristides Diaz-Pedrosa, Shaffer's Footnote, 109 W. VA. L. REv. 17, 24 (assuming that the due process jurisdictional requirement falls within the local "rules of procedure" in Article III); also citing as contrary authority, William W. Park \& Alexander A. Yanos, Treaty Obligations and National Law: Emerging Conflicts in International Arbitration, 58 Hastings L.J. 251, 262 (Dec. 2006) (maintaining that such approach is not supported by the drafting history of the New York Convention)).

125. See e.g., STX Pan Ocean Shipping Co. Ltd. v. Progress Bulk Carriers Ltd., Slip Copy, 2013 WL 1385017 (S.D.N.Y.,2013) (examining a State of New York long arm statute).

126. See Shaffer v. Heitner, 433 U.S. 186 (1977).

127. See Burnham v. Sup. Ct. Cal., 495 U.S. 604 (1990).

128. See e.g., Perkins v. Benguet Consol. Mining Co., 342 U.S. 437 (1952); see also Goodyear Dunlop Tires Operations, S.A., et al. v. Brown, 131 S.Ct. 2846 (2011) (finding that North Carolina could not assert general, or "all-purpose jurisdiction" over defendants that were foreign companies).

129. See Sonera Holding B.V. v. Cukurova Holding A.S., 895 F. Supp. 2d 513, 523 (S.D.N.Y. 2012) rev'd on other grounds, _ F.3d —, 2014 WL 1645255 (2d Cir. 2014) (reversing for lack of personal jurisdiction).

130. See Daimler AG v. Bauman, 134 S.Ct. 746 (2014) (finding that defendant was not subject to general jurisdiction in forum state based on its subsidiary's contacts); Goodyear Dunlop Tires Operations, S.A. v. Brown, 131 S.Ct. 2846, 2851, 2857 (2011) (finding that foreign subsidiaries of American parent company did not have sufficient contacts for specific or general jurisdiction in forum state, but also noting that the 
Personal jurisdiction becomes more problematic, however, when neither the defendant nor his property is located in the forum stateand this has occasionally been the case in the context of petitions to enforce or confirm foreign arbitral awards in the United States. Under these circumstances, it becomes more likely that it will be inconvenient, expensive and unfair for the defendant to be required to travel to the forum state to defend himself from potential deprivation. As a result, at that point, courts in the United States must determine whether the defendant has sufficient "minimum contacts" with the forum state so that the court's assertion of personal jurisdiction will not offend "traditional notions of fair play and substantial justice."131

\section{H. Forum Non Conveniens}

In the United States, even if a court has personal jurisdiction, it may decide as a matter of discretion that the case would be better heard in another state's tribunals. The court will then dismiss the case based on forum non conveniens. The forum non conveniens doctrine requires a three-step analysis. First, the court must determine the degree of deference it will give to the petitioner's choice of forum. Although the New York Convention specifically provides that courts may not impose "substantially more onerous conditions" on the enforcement of foreign arbitral awards than on domestic awards, ${ }^{132}$ some courts have explained explicitly that they extend less deference to foreign petitioners' choice of a United States forum and use a sliding scale to determine the precise degree of deference they will apply. ${ }^{133}$ Second, the court must consider whether the alternative forum proposed by the respondent is adequate to adjudicate the dispute. An alternative forum is ordinarily adequate if the defendants are amenable to service of process there and the forum permits litigation of the subject matter of the dispute. ${ }^{134}$ The alternative fo-

respondents belatedly urged treatment of the parent and subsidiaries as a "single enterprise" or "unitary business" and thus forfeited the contention).

131. Int'l Shoe Co. v. Washington, 326 U.S. 310, 316, 66 S.Ct. 154, 90 L.Ed. 95 (1945); see First Investment Corp. of the Marshall Islands v. Fujian Mawei Shipbuilding, Limited, 703 F.3d 742, 746 (5th Cir. 2013) (relying on the Due Process Clause and the potential for significant deprivation to affirm lower court's dismissal of an award confirmation action for lack of personal jurisdiction when the award debtor was neither present nor in possession of property in the United States).

132. See in re Monegasque De Reassurances S.A.M. v. Nak Naftogaz of Ukraine, 311 F.3d 488, 495 (2d Cir. 2002) (citing Am. Dredging Co. v. Miller, 510 U.S. 443 (1994)).

133. See id. at 498; Figueiredo Ferraz E. Engenharia de Projeto Ltda. v. Rep. of Peru, 665 F.3d 384, 390 (2d Cir. 2011) (affirming "somewhat reduced deference"); see also Sonera Holding B.V. v. Cukurova Holding A.S., 895 F.Supp.2d 513, 523 (S.D.N.Y. 2012) (regarding sliding scale), rev'd on other grounds, Sonera Holding B.V. v. Cukurova Holding A.S., _J.3d _, 2014 WL 1645255 (2d Cir. 2014).

134. See Piper Aircraft Co. v. Reyno, 454 U.S. 235, 254 n.25 (1981). 
rum is not inadequate simply because it does not afford plaintiff the identical causes of action or relief available in the plaintiff's chosen forum. ${ }^{135}$ Third, the court balances the public and private interests implicated in the choice of forum. ${ }^{136}$ The private factors focus on the convenience of the litigants-e.g., the ease of access to evidence; the availability of means to compel attendance by unwilling witnesses; the cost of obtaining attendance of willing witnesses; the ability to view premises if needed; and other practical problems that are relevant to making the proceeding easy, expeditious and inexpensive for the litigants. ${ }^{137}$ The public factors deal primarily with the administrative difficulties that the case may cause for the courts in the United States-e.g., exacerbating current court congestion; imposing jury duty upon citizens whose community has no relationship to the litigation; the local interest in resolving local disputes; and the problems of legal research and interpretation that can be implicated when a United States court is required to apply foreign law. ${ }^{138}$

In general, a court will dismiss on the grounds of forum non conveniens only if the petitioner's choice of forum represents inappropriate forum shopping, an alternative forum exists and has jurisdiction to hear the matter, and proceeding in the chosen United States forum "would establish ... oppressiveness and vexation to a [respondent] out of all proportion to [the] [petitioner's] convenience, or . . . the chosen forum is inappropriate because of considerations affecting the court's own administrative and legal problems."139

As with the defense of personal jurisdiction, the Convention does not specifically list forum non conveniens as a defense to the enforcement of awards. In Monegasque de Reassurances S.A.M. v. NAK Naftogaz of Ukraine, ${ }^{140}$ however, the Second Circuit found that the doctrine of forum non conveniens represented a "rule of procedure" as described in Article III and, for this and other reasons, affirmed the district court's dismissal of an enforcement action on the basis of forum non conveniens. ${ }^{141}$

135. Norex Petroleum, 416 F.3d. at 158

136. Id. at 153.

137. Piper Aircraft Co. v. Reyno, 454 U.S. at n.6.

138. Id. In re Monegasque de Reassurances S.A.M. v. NAK Naftogaz of Ukraine, 311 F.3d 488, 500. (In a seminal forum non conveniens case, the district court listed the public factors as follows: "the administrative difficulties flowing from court congestion; the 'local interest in having localized controversies decided at home; the interest in having the trial of a diversity case in a forum that is at home with the law that must govern the action; the avoidance of unnecessary problems in conflict of laws, or in the application of foreign law; and the unfairness of burdening citizens in an unrelated forum with jury duty."). Piper Aircraft Co. v. Reyno, 454 U.S. at 241 n.6.

139. Cont'l Transfert Technique Limited v. Federal Government of Nigeria, 697 F.Supp.2d 46, 57 (D.C. 2010).

140. In re Monegasque De Reassurances S.A.M. v. NAK Naftogaz of Ukraine, 311 F.3d 488 .

141. Id. at 501 . 
The application of forum non conveniens has become rather heated recently in the United States, especially since the decision in Figueiredo $v$. Republic of Peru ${ }^{142}$ in which the court dismissed an action to enforce an arbitral award on the basis of forum non conveniens. In that case, Peru-which the court described as a developing country-had a statute placing a percentage cap on the amount that it could be required to pay each year to arbitral award creditors. The petitioner in Figueiredo acknowledged that it sought enforcement and access to the Peru's assets in the United States as a means to avoid the long wait for full payment that would be occasioned by the cap. The court in Figueiredo found that Peru's financial concerns, as expressed in its statute, should be considered a public interest and factored into the third step of the forum non conveniens analysis. In a very influential dissent, Judge Gerard E. Lynch urged that while Peru's financial concerns might be relevant to a choice of law analysis, they were not among the public factors to be considered in forum non conveniens analysis. ${ }^{143}$

Judge Lynch also noted that "because arbitrators have no power to enforce their judgments, international arbitration is viable only if the awards issued by arbitrators can be easily reduced to judgment in one country or another and thereby enforced against the assets of the losing party."144 The court in Sonera Holding v. Cukurova Holding, ${ }^{145}$ quoted Judge Lynch approvingly as it explained its decision to refuse to dismiss an award enforcement case based on forum non conveniens. ${ }^{146}$ Indeed, the Sonera court went on to note that the courts of New York have a public interest in "convincing the international business community of the benefits of selecting New York law and a New York forum in order to ensure fairness and predictability in their commercial relationships."147

The second Circuit recently vacated the Sonera Court's judgment, reversing on personal jurisdiction grounds, and it is important to note that courts in the United States appear to use forum non conveniens quite sparingly as a basis for refusing to entertain actions to enforce arbitral awards. ${ }^{148}$ Indeed, Sonera is a case in which the award debtor had no assets in the United States and yet the district court had refused to use the doctrine of forum non conveniens as a basis for dismissal. ${ }^{149}$

142. Figueiredo, 665 F.3d 384

143. Figueiredo, 665 F.3d at 407-08 (Lynch, J., dissenting).

144. Id. at 395 .

145. Sonera Holding, 895 F.Supp.2d 513.

146. Sonera Holding, 895 F.Supp.2d at 524.

147. Sonera Holding, 895 F.Supp.2d at 525.

148. TMR Energy Ltd. v. State Property Fund of Ukraine, 411 F.3d 296, 303-04 (D.C.Cir. 2005).

149. See e.g., Sonera Holding, 895 F.Supp.2d 513 (concluding that Sonera's failure to identify U.S. assets does not establish a lack of a good-faith basis for seeking en- 


\section{Adjournment, Stay, Dismissal with and without Prejudice}

A court's refusal to recognize or enforce an arbitral award is likely to be deemed a dismissal with prejudice and thus would represent a decision on the merits that is entitled to preclusive effect. ${ }^{150}$

Rather than refuse to recognize or enforce an arbitral award, a court may under certain circumstances "adjourn the decision on the enforcement" of an arbitral award under Article VI of the Convention:

If an application for the setting aside or suspension of the award has been made to a competent authority referred to in article $\mathrm{V}(\mathbf{1})(\mathrm{e})$, the authority before which the award is sought to be relied upon may, if it considers it proper, adjourn the decision on the enforcement of the award . . ${ }^{151}$

Adjournment can be understood to constitute either a "stay" or a dismissal without prejudice. ${ }^{152}$ If adjournment is understood as a stay, this decision permits the court to maintain some form of control over the enforcement proceeding even as it postpones decision-making. Dismissal without prejudice, in contrast, does not permit the court to maintain any control over the proceeding. Rather, this decision simply permits the petitioner to return to court in the future with the same request for recognition and enforcement.

The alternative of adjournment is most appropriate when a competing foreign action has been brought, especially in the originating country. On one hand, United States courts favor the prompt enforcement of arbitral awards, and adjournment represents delay. On the other hand, if the parallel proceeding is occurring in the originating country and it is possible that the award will be set aside, a United States court may be "acting improvidently" 153 if it proceeds with enforcement. ${ }^{154}$ Either a stay or a dismissal without prejudice permits a

forcement in the U.S. and observing that Cukurova may acquire property in the U.S., and Sonera will have a "judgment in hand").

150. See Telcordia Tech Inc. v. Telkom SA Ltd., 458 F.3d 172, 179 (3d Cir. 2006).

151. New York Convention, supra note 1, at Article VI.

152. See Telecordia Tech Inc., 458 F.3d at 180.

153. Europcar Italia, S.p.A. v. Maiellano Tours, Inc., 156 F.3d 310, 317 (2d Cir. 1998).

154. The D.C. Circuit has approvingly cited to the Second Circuit's development of a list of six factors to be weighed by a district court to determine whether adjournment is the appropriate course of action:

(1) the general objectives of arbitration-the expeditious resolution of disputes and the avoidance of protracted and expensive litigation; (2) the status of the foreign proceedings and the estimated time for those proceedings to be resolved; (3) whether the award sought to be enforced will receive greater scrutiny in the foreign proceedings under a less deferential standard of review; (4) the characteristics of the foreign proceedings, including (i) whether they were brought to enforce an award (which would tend to weigh in favor of a stay) or to set the award aside (which would tend to weigh in favor of en- 
United States court to express "comity in the international arena," especially if there are competing actions pending in the United States and elsewhere. ${ }^{155}$

forcement); (ii) whether they were initiated before the underlying enforcement proceeding so as to raise concerns of international comity; (iii) whether they were initiated by the party now seeking to enforce the award in federal court; and (iv) whether they were initiated under circumstances indicating an intent to hinder or delay resolution of the dispute; (5) a balance of the possible hardships to each of the parties ...; and (6) any other [relevant] circumstances ....

Cont'l Transfert v. Fed. Gov't of Nigeria, 697 F.Supp.2d 46, 60 (D.D.C. 2010) (quoting Europcar, 156 F.3d 310 at 317-16).

155. Telecordia Tech Inc., 458 F.3d at 181 (suggesting this as a benefit of dismissal without prejudice and citing to Stonington Partners, Inc. v. Lernout \& Hauspie Speech Prod. N.V., 310 F.3d 118, 126 (3d Cir. 2002). 